\title{
A snakebite caused by a bushmaster (Lachesis muta): report of a confirmed case in State of Pernambuco, Brazil
}

\author{
Pedro Henrique Santana de Lima ${ }^{[1]}$ and Vidal Haddad Junior ${ }^{[2]}$
}

[1]. Centro de Assistência Toxicológica de Pernambuco, Secretaria Executiva de Assistência à Saúde, Recife, Pernambuco, Brazil. [2]. Faculdade de Medicina de Botucatu, Universidade Estadual Paulista, Botucatu, São Paulo, Brazil.

\begin{abstract}
We report a case of envenomation caused by a bushmaster (Lachesis muta) in a male child in State of Pernambuco, Brazil. The victim showed discrete local manifestations, but presented altered blood coagulation 2 hours after the bite. Ten ampoules of bothropic-lachetic antivenom therapy were administered, and 48 hours later, the patient showed discrete edema, pain, and ecchymosis around the bite and normal blood coagulation. The patient was discharged 5 days after the envenomation. The prompt administration of specific treatment was important for the favorable outcomes observed.
\end{abstract}

Keywords: Bushmaster. Snakebite. Lachesis. Bites and stings. Venomous animals.

\section{INTRODUCTION}

Snakebites are among the most serious causes of envenomation around the world and necessitate early administration of adequate antivenom therapy ${ }^{(1)}$. Snakebites occur all over Brazil, and are therefore a recognized public health issue. According to the Ministry of Health, 31,148 envenomations caused by snakes occurred in 2011, 29,322 in 2012, and 25,302 in 2013, with 143, 129, and 108 deaths, respectively, attributed to snakes from the Elapidae family (genus Micrurus) and Viperidae family (genera Bothrops, Crotalus, and Lachesis) $)^{(2)(3)}$.

The Bushmasters are snakes belonging to the Lachesis genus, and only one species is found in Brazil, Lachesis muta. They are the largest Brazilian venomous snakes, measuring up to $4.5 \mathrm{~m}$ (14.75 feet) in length. This terrestrial species has nocturnal habits and during the day is found in other animal burrows and hollows of fallen trees, preying on mainly small mammals ${ }^{(4)(5)}$.

Lachesis muta is known as Surucucu, Surucutinga, Surucucu-de-fogo, or Surucucu-pico-de-jaca in Pernambuco, Brazil. This species inhabits remnants of the Atlantic and Amazonian rainforests; the Atlantic forest is distributed from the North of Rio de Janeiro (Southeast region) to Paraíba (Northeast region). The coastal region of Pernambuco is small and contains only vestigial areas of the Atlantic rainforest

Corresponding author: Dr. Vidal Haddad Junior. Depto. de Dermatologia/FMB/ UNESP. Rubião Jr, 18618-970 Botucatu, São Paulo, Brasil.

Phone: 5514 3882-4922

e-mail: haddadjr@fmb.unesp.br

Received 4 May 2015

Accepted 28 May 2015 that formerly covered the Northeast region. It is an anthropic region with intense human activities, owing to the cane sugar culture, and with vestiges of the well-conserved subperennial Atlantic rainforest, mixed with a semideciduous forest. These environmental characteristics are advantageous to the survival of Lachesis muta, a snake that lives in large forests.

Owing to the habitation preferences of Lachesis muta, human envenomations are not common ${ }^{(6)(7)(8)(9)}$. The mechanism of action of the venom and the local and systemic symptomatology resemble those of the bothropic toxin, which make the diagnosis confusing. Pain, edema, erythema, and heat are the common local clinical signs. The coagulation time can also alter, contributing to systemic hemorrhage. The patient can present vagal stimulation such as bradycardia, diarrhea, arterial hypotension, and $\operatorname{shock}^{(6)(7)(8)(9)}$. The specific treatment is the lachetic antivenom or bothropic-lachetic antivenom ${ }^{(1)}$.

\section{CASE REPORT}

Herein, we describe a case of envenomation caused by Lachesis muta in a 13-year-old male child treated at Centro de Assistência Toxicológica (CEATOX), Recife, State of Pernambuco. The patient, an inhabitant of the coastal area of Igarassu, was admitted to the Hospital da Restauração owing to a snakebite in the left foot that occurred 2 hours ago (Figure 1). The snake was killed by the family of the victim, identified at the Laboratory of Venomous Animals and Toxins of the Federal University of Pernambuco (Laboratório de Animais Peçonhentos e Toxinas/Universidade Federal de Pernambuco - LAPTx/UFPE) and sent to the CEATOX-PE (Figure 1).

The patient complained of local and abdominal pain and emesis. Physical examination revealed somnolence, mild gingival hemorrhage, apparent bite marks, and mild erythema and edema in the injured area. Altered coagulation was detected 


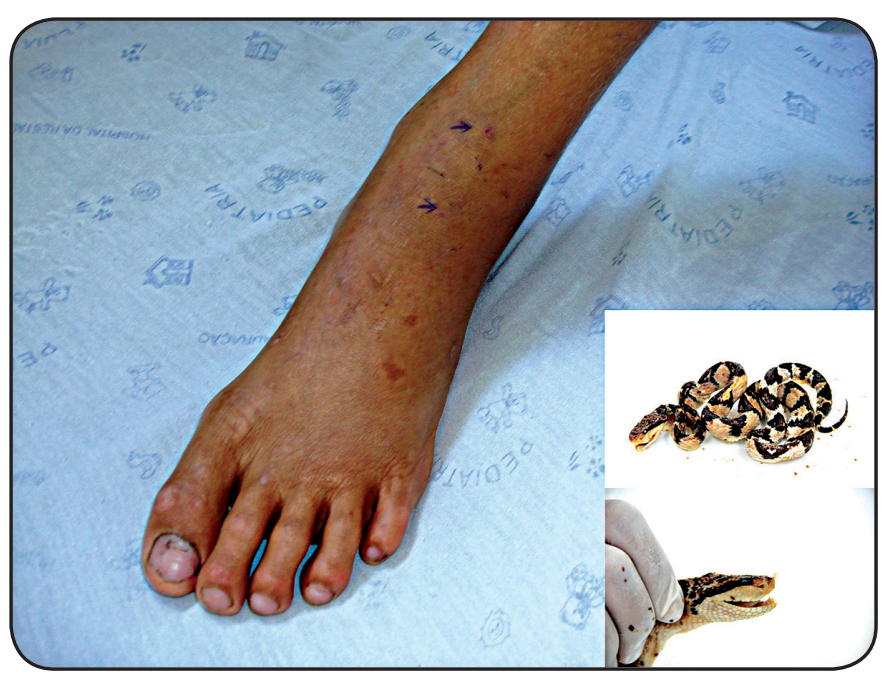

FIGURE 1 - Marks of the fangs and mild erythema and edema in the left foot of the victim. In the details: the Lachesis muta responsible for the bite in the child, which measured about $1.5 \mathrm{~m}$ in length (4 feet).

(coagulation time, $>10$ minutes; bleeding time, 2 minutes 30 seconds; prothrombin time and activated prothrombin time, not detectable). Renal function and platelet counts were normal. Ten ampoules of the bothropic-lachetic antivenom were administered, preceded by corticosteroid therapy to prevent allergic reactions. The local manifestations and systemic symptoms improved in about 2 hours after the antivenom therapy, and 48 hours after the treatment, coagulation normalized and only very mild edema and ecchymosis was observed around the region of the bite. The patient was discharged from the CEATOX-PE 5 days after the accident.

\section{DISCUSSION}

Lachetic envenomation presents characteristic local effects such as pain, edema, ecchymosis, hemorrhagic blisters, and tissue necrosis, causing sequelae such as muscular tissue loss, and occasionally, amputation of the affected extremities. The altered coagulation occurs mainly due to defibrination. Other symptoms that patients may present are nausea, emesis, diarrhea, arterial hypotension, bradycardia, abdominal pain, and renal failure, which typically occurs if the envenomation is not properly identified and treated with urgency ${ }^{(6)(7)(8)(9)}$. However, this case revealed only characteristic initial signs and symptoms and presented excellent results with the precocious specific treatment for Lachesis bites.

In conclusion, snakebites present complex signs and symptoms, whose evolution depends on the time between the bite and the adequate treatment. The clinical manifestations of envenomation caused by Lachesis snakes are poorly described because such bites are rare or not reported. To decrease the patient's risk of adverse outcomes, immediate identification of the specimen and prompt administration of specific treatment, as observed in this case, is necessary. Therefore, it is very important to conduct maintenance programs with continuous capacitation of professionals from different health services that have the potential to assist with snakebite envenomations.

\section{CONFLICT OF INTEREST}

There are no conflicts of interests regarding this work. The report of an isolated case is authorized without submission to the local ethics committee.

\section{REFERENCES}

1. Málaque CMSA, França FOS. Acidente laquético. In: Cardoso JLC, França FOS, Wen FH, Malaque CMS, Haddad Jr V, editors. Animais Peçonhentos no Brasil: biologia, clínica e terapêutica dos acidentes. São Paulo: Editora Sarvier; 2003. p. 87-90.

2. Fundação Nacional de Saúde. Manual de Diagnóstico e Tratamento de Acidentes por Animais Peçonhentos. $2^{\text {nd }}$ edição. Brasília: Ministério da Saúde; 2001.

3. Ministério da Saúde. Animais Peçonhentos (Internet). Brasília: Ministério da Saúde; 2014. (Cited 2015 May 21). Available at http:// portalsaude.saude.gov.br/index.php/o-ministerio/principal/leiamais-o-inisterio/1025-secretaria-svs/vigilancia-de-a-a-z/animaispeconhentos-serpentes/12-animais-peconhentos-serpentes/13712 situacao-epidemiologica-dados

4. Zamudio KR, Greene HW. Phylogeography of the Bushmaster (Lachesis muta: Viperidae): implications for neotropical biogeography, systematic, and conservation. Biol J Linn Soc 1997; 62:421-442.

5. Campbell JA, Lamar WW. Venomous reptiles of the western hemisphere. Ithaca: Comstock Publishing Associates; 2004.

6. Pardal PPO, Souza SM, Monteiro MRCC, Fan HW, Cardoso JLC, França FOS, et al. Clinical trial of two antivenoms for the treatment of Bothrops and Lachesis bites in the north eastern Amazon region of Brazil, Trans R Soc Trop Med Hyg 2004; 98:28-42.

7. Jorge MT, Sano-Martins IS, Tomy SC, Castro SC, Ferrari RA, Ribeiro LA, et al. Snakebite by the bushmaster (Lachesis muta) in Brazil: case report and review of the literature. Toxicon 1997; 35: 545-554.

8. Pardal PPO, Bezerra IS, Rodrigues LS, Pardal JSO, Farias PHS. Acidente por Surucucu (Lachesis muta muta) em Belém-Pará: relato de caso. Rev Para Med 2007; 21:37-42.

9. Carvalho-Junior AM, Alencar VP, Costa FG, Cabral B, Dias WPF, Arruda Junior ER, et al. Acidentes ofídicos por surucucu (Lachesis muta rhombeata): relato de dois casos atendidos no HU. CCS 1994; 13:11-14. 